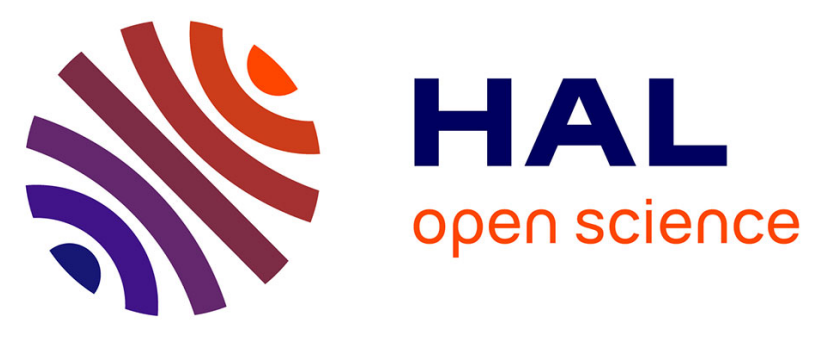

\title{
Seasonal ovulatory activity and plasma prolactin concentrations in the Spanish ibex(Capra pyrenaica hispanica) maintained in captivity
}

Julián Santiago-Moreno, Amelia Gómez-Brunet, Antonio González-Bulnes, Benoit Malpaux, Philippe Chemineau, Antonio Pulido-Pastor, Antonio

López-Sebastián

\section{To cite this version:}

Julián Santiago-Moreno, Amelia Gómez-Brunet, Antonio González-Bulnes, Benoit Malpaux, Philippe Chemineau, et al.. Seasonal ovulatory activity and plasma prolactin concentrations in the Spanish ibex(Capra pyrenaica hispanica) maintained in captivity. Reproduction Nutrition Development, 2003, 43 (3), pp.217-224. 10.1051/rnd:2003023 . hal-00900451

\section{HAL Id: hal-00900451 https://hal.science/hal-00900451}

Submitted on 1 Jan 2003

HAL is a multi-disciplinary open access archive for the deposit and dissemination of scientific research documents, whether they are published or not. The documents may come from teaching and research institutions in France or abroad, or from public or private research centers.
L'archive ouverte pluridisciplinaire HAL, est destinée au dépôt et à la diffusion de documents scientifiques de niveau recherche, publiés ou non, émanant des établissements d'enseignement et de recherche français ou étrangers, des laboratoires publics ou privés. 


\title{
Original article
}

\section{Seasonal ovulatory activity and plasma prolactin concentrations in the Spanish ibex (Capra pyrenaica hispanica) maintained in captivity}

\author{
Julián SANTIAGO-MORENO ${ }^{a *}$, Amelia GÓMEZ-BRUNET ${ }^{\mathrm{a}}$, \\ Antonio GONZÁlEZ-BULNES ${ }^{\mathrm{a}}$, Benoit MALPAUX ${ }^{\mathrm{b}}$, \\ Philippe CHEMINEAU ${ }^{\mathrm{b}}$, Antonio PULIDO-PASTOR ${ }^{\mathrm{c}}$, \\ Antonio LÓPEZ-SEBASTIÁN ${ }^{\mathrm{a}}$
}

\footnotetext{
${ }^{a}$ Dpto. Reproducción Animal, SGIT-INIA, avda. Puerta de Hierro km 5.9, 28040 Madrid, Spain

${ }^{b}$ UMR INRA-CNRS-Université de Tours, Physiologie de la Reproduction et des Comportements, 37380 Nouzilly, France

${ }^{\mathrm{c}}$ Consejería de Medio Ambiente de la Junta de Andalucía, DP de Málaga, Calle Mauricio Moro, 2, Edificio Eurocom, 29006 Málaga, Spain
}

(Received 11 November 2002; accepted 26 February 2003)

\begin{abstract}
Seasonal changes in ovulatory activity, assessed by the measurement of plasma progesterone and plasma prolactin concentrations were monitored in 10 Spanish ibex females captured in the National Wildlife Reserve of Sierra Nevada (South Spain, $37^{\circ} \mathrm{N}$ ). Five of the 10 female ibex showed ovulatory activity with a mean ( \pm s.e.m.) duration of the oestrous cycle of $19.4 \pm 1$ days (range: 17-23 days). On average, the five cyclic females weighed $28 \pm 0.9 \mathrm{~kg}$. Progesterone cycles occurred only in animals older than 4 years of age. Ovulatory activity extended from December to January. The duration of the breeding season was $43.2 \pm 7.7$ days. Ibex females younger than 4 years of age had a body weight lower $(P<0.01)$ than that of adults and none of them displayed ovulations. Plasma concentrations of prolactin levels were significantly affected by season $(P<0.05)$, following a trend that was roughly parallel to daylength. The highest values occurred in the spring $(119.7 \pm$ $\left.21.4 \mathrm{ng} \cdot \mathrm{mL}^{-1}\right)$ and the summer $\left(139.3 \pm 19.8 \mathrm{ng} \cdot \mathrm{mL}^{-1}\right)$, the lowest values in the autumn $(26 \pm$ $\left.7.4 \mathrm{ng} \cdot \mathrm{mL}^{-1}\right)$ and in the winter $\left(19.7 \pm 3.2 \mathrm{ng} \cdot \mathrm{mL}^{-1}\right)$. Our results showed a very restricted breeding season, despite the fact that the Spanish ibex originates from and lives in a temperate latitude, revealing a remarkably good adaptation to the harsh climatic and nutritional conditions of their mountainous habitat.
\end{abstract}

breeding season / ovulation / progesterone

\section{INTRODUCTION}

The Spanish ibex (Capra pyrenaica) is a wild caprine originating exclusively in the mountains of the Iberian Peninsula. Only two of the four original subspecies (C. p. hispanica, C. p. victoriae, C. p. lusitanica, C. p. pyrenaica) [1] still exist. C. p. lusitanica became extinct

\footnotetext{
*Corresponding author: moreno@inia.es
} 
last century, and $C$. $p$. pyrenaica has recently and definitively disappeared. The Spanish ibex is currently considered as a vulnerable species [2] because of the loss of heterozygosity by inbreeding in small isolated populations formed by habitat fragmentation, and because of low food availability in high density populations. This fragmentation of the population leads to a loss of natural population control mechanisms and increases the risks associated with inbreeding, such as unmasking of deleterious recessive genes, fertility problems and a decreased function of the immune system [3]. In this regard, studies on reproduction in the Spanish ibex are highly relevant to the preservation of genetic resources in wildlife. A good knowledge of their reproductive physiology is therefore a prerequisite for a successful use of methods of assisted reproduction, widely used in domestic animals (gamete cryopreservation, artificial insemination, embryo transfer and in vitro fertilisation) $[4,5]$. They allow dispersion of the existing gene pools with minimal transport of animals and the introduction of new genes from wild populations into captive breeding programmes, counteracting a possible risk of extinction in one specific Spanish ibex population.

The second major point of interest is related to the use of the Spanish ibex as a valuable animal model to study environmental influences on seasonal breeding activity and endocrine response. Prolactin secretion is increased or decreased in response to variation in photoperiod in all photoperiodic mammals studied so far, with the highest and lowest concentrations occurring during the summer and winter, respectively [6]. Among other functions, prolactin has also been implicated in regulating gonadal activity and sexual behaviour $[7,8]$. The temporal pattern of reproductive activity in many mammalian species is affected by the geographic origin (latitude). In the mountains of northern Ethiopia $\left(10^{\circ} \mathrm{N}\right.$ latitude), the Walia ibex (Capra walie) is distinguished from other ibex species in its ability to breed at all times of the year, although most often the Walia Ibex mates during the rut season, from February until June $[9,10]$. In contrast, at high latitudes $\left(45^{\circ} \mathrm{N}\right)$, the Alpine ibex (Capra ibex ibex) shows a mating season restricted to December [11]. Although the Spanish ibex originates and lives in a moderate latitude $\left(37^{\circ} \mathrm{N}\right)$, field observations have shown that the period of the rut is very short (December-January) in many wild populations [12]. A wide range of variation in the length of the sexual active phase has, however, been observed between populations of the Spanish ibex located in neighbouring areas but with very differentiated climatic characteristics [13]. Considering that previous reports have described differences in the extension of the breeding season in wild species when behavioural methods and other precise analytical methods are compared [14], analytical methods to accurately assess the seasonal ovulatory cycle of the Spanish ibex are required.

The present work was conducted to characterise the seasonal ovulatory activity in the Spanish ibex, by measuring progesterone concentrations in peripheral blood, and to determine seasonal changes in plasma prolactin.

\section{MATERIALS AND METHODS}

\subsection{Experimental design and animals}

In July 1999, ten Spanish ibex females (Capra pyrenaica hispanica), aged 3 months to 7 years, were captured in a National Wildlife Park (Sierra Nevada, Southeastern Spain; $\left.36^{\circ} 55^{\prime}-37^{\circ} 10^{\prime} \mathrm{N}, 2^{\circ} 34^{\prime}-3^{\circ} 40^{\prime} \mathrm{W}\right)$. The animals were transferred to the Animal Reproduction Department, INIA (Madrid; $40^{\circ} 25^{\prime} \mathrm{N}, 3^{\circ} 68^{\prime} \mathrm{W}$ ), and housed in two sand-floor stables $\left(250 \mathrm{~m}^{2}\right)$ adapted for maintenance of the ibex, with a partial roof cover, under natural photoperiod. To alleviate stress during the experimental procedures, an acclimatisation period to routine restraints 
and handling, of at least 6 months, was allowed before the beginning of the experiment. During this period, animals were accustomed to going into a small stall to allow blood collection. In addition, during manipulations the eyes of the animals were covered with a mask. The ibex age was assessed by their teeth (replacement of deciduous teeth) and horns (marks of growth) [15]. At the onset of the experiment (October 2000) the female ibexes were $1.5-8$ years of age and were classified into three classes [16]: yearling (1.5 years of age, $n=2)$; sub-adult ( $2-4$ years of age, $n=3$ ); adult ( $>4$ years of age, $n=5)$. Total replacement of deciduous teeth and full physical development (body weight and horn growth) is only reached in the adult class (mean adult weight: $31 \mathrm{~kg}$ ) [15, 17]. The ibexes were fed a balanced diet consisting of barley grain, barley straw, and dry alfalfa. The animals had free access to water and mineral blocks containing minerals and vitamins. All animals maintained a good health condition throughout the experimental period.

The animals were weighed once in December, coinciding with the period of sexual activity in the wild conditions [13].

\subsection{Hormone assay}

Blood samples were collected twice weekly for 13 months, by jugular venepuncture and centrifuged at $1500 \mathrm{~g}$ for $15 \mathrm{~min}$. The plasma was separated and stored at $-15^{\circ} \mathrm{C}$ until progesterone and prolactin analyses were performed.

Progesterone determinations were performed in duplicate $200 \mu \mathrm{L}$ aliquots of plasma by radioimmunoassay (RIA) according to the procedure developed by Lopez-Sebastian et al. [18]. The inter- and intra-assay coefficients of variation were $13.6 \%(n=6)$ and $10.4 \%(n=8)$ respectively, and the limit of detection of the assay was $0.16 \mathrm{ng} \cdot \mathrm{mL}^{-1}$. The mean extraction efficiency was $84.3 \pm 3.2 \%(n=10)$.
The prolactin analysis was performed only in two of the samples recovered each month (two weeks apart). Plasma concentrations of prolactin were determined by RIA in duplicate $100 \mu \mathrm{L}$ aliquots by a previously described method [19]. All samples were analysed in a single assay. The limit of detection of the assay was $0.2 \mathrm{ng} \cdot \mathrm{mL}^{-1}$ and the intra-assay coefficient of variation was $9.3 \%(n=8)$.

\subsection{Analysis}

The date of onset of ovarian activity was taken as the date before progesterone rose above $0.5 \mathrm{ng} \cdot \mathrm{mL}^{-1}$ in two consecutive plasma samples [20]. The date of the end of ovarian activity was the first sample date with progesterone concentrations lower than $0.5 \mathrm{ng} \cdot \mathrm{mL}^{-1}$ followed by basal levels in successive plasma samples. The effect of age on the establishment of ovulatory activity was analysed by ANOVA. In order to perform this analysis, yearling and subadult animals were pooled, considering only two groups of age (older and younger than 4 years old). The times of the peak and nadir (basal level) of the annual cycle in the concentration of prolactin was calculated for each animal using a three-point moving average [6]. This involved calculating the mean value for each three consecutive time points and repeating this throughout the year to determine the time of the maximum or minimum value for each animal. The timing of the increase and attainment of the basal level in prolactin were determined using a graph of the accumulated sums of the plasma concentrations of prolactin for each animal. Lines were fitted to the main slopes of the graph. The intercepts related to the $x$ axis gave the time of the increase and attainment of the basal level in prolactin [21]. Prolactin concentrations had a skewed distribution and were therefore logtransformed before analysis. The effect of the season on the mean circulating levels of prolactin was assessed by one way 
repeated-measures ANOVA. Differences in body weight were analysed by a $t$-test. The results are presented as mean \pm s.e.m. All statistical procedures were performed with the BMDP, Statistical Software, Inc.

\section{RESULTS}

Five of the 10 female ibex showed ovulatory activity (Fig. 1) with 1 to 3 progesterone cycles (peaks of $1.4 \pm 0.1 \mathrm{ng} \cdot \mathrm{mL}^{-1}$ ). The mean duration ( \pm s.e.m) of the oestrous cycle was $19.4 \pm 1$ days (range: 17-23 days). Two females showed 1 short cycle of progesterone (10-14 days and average maximum values of $0.8 \pm 0.2 \mathrm{ng} \cdot \mathrm{mL}^{-1}$ ) prior or following a cycle of normal duration. A sixth female (3.5 years of age) showed only a short cycle (12 days) with a peak of $1.2 \mathrm{ng} \cdot \mathrm{mL}^{-1}$ of progesterone. This animal was not included in the females with ovarian activity because this cycle was not followed by any cycle of normal duration. The other 4 females did not show any ovulatory cycle. The first cycle of progesterone appeared between 3 and 27 December (mean \pm s.e.m: December $16 \pm 5$ days). The end of the seasonal ovulatory activity stretched from 15 January to 9 February (January $29 \pm$ 4 days). The duration of the breeding season was $43.2 \pm 7.7$ days.
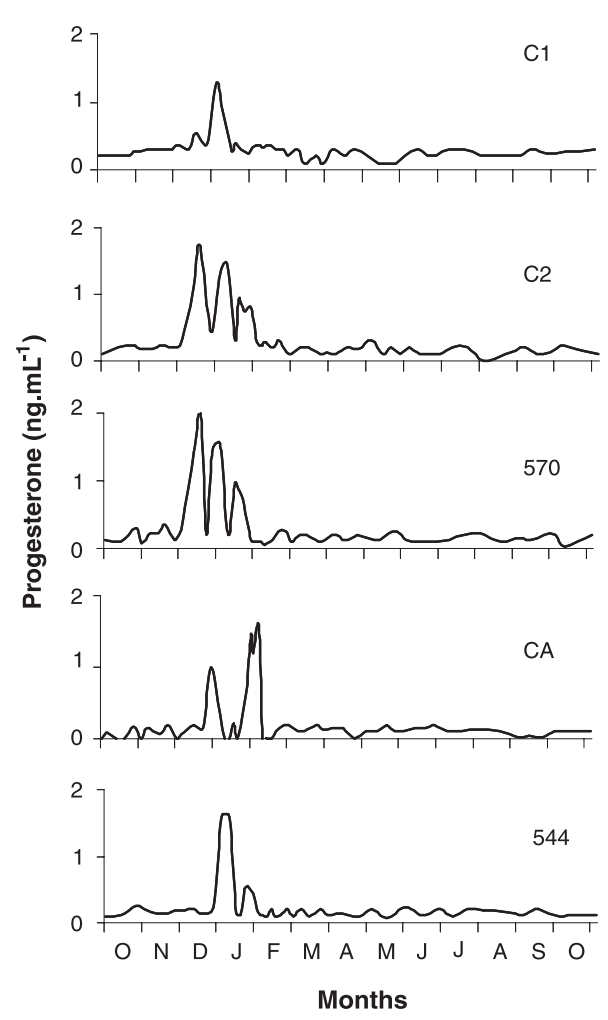

Figure 1. Cyclical ovarian activity in 5 Spanish ibex females, determined by progesterone concentrations in blood samples collected twice weekly.

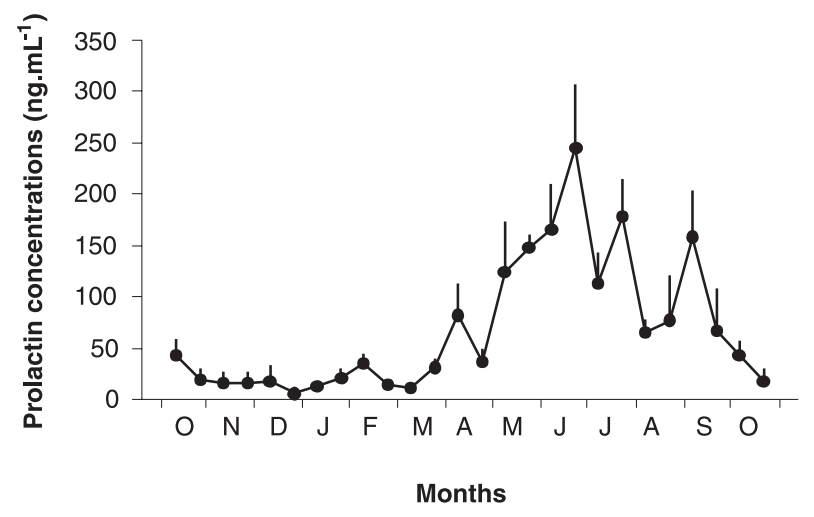

Figure 2. Changes in plasma concentrations of prolactin (mean \pm s.e.m.) throughout the year in Spanish ibex females $(n=10)$. (Blood samples collected twice monthly). 
ANOVA revealed an influence of age $(P<0.001)$ on the establishment of ovulatory activity. Initial progesterone increases occurred only in animals older than 4 years of age (adults, $n=5$ ). On average, adult females weighed $28 \pm 0.9 \mathrm{~kg}$. Ibex females younger than 4 years of age did not display ovarian activity $(n=4)$ or showed only a short ovarian cycle $(n=1)$. The body weights (mean \pm s.e.m) in both yearling $(17.4 \pm 0.03 \mathrm{~kg})$ and sub-adult $(22.5 \pm 1.6 \mathrm{~kg})$ animals were lower than that of the adult ones $(P<0.01)$.

The profile of prolactin concentrations followed a trend that was roughly parallel to daylength (Fig. 2). The timing of the increase in prolactin concentrations and attainment of basal levels were April and October, respectively. Mean ( \pm s.e.m) circulating levels were significantly affected by season $(P<0.05)$. The highest values occurred in the spring $\left(119.7 \pm 21.4 \mathrm{ng} \cdot \mathrm{mL}^{-1}\right)$ and summer $\left(139.3 \pm 19.8 \mathrm{ng} \cdot \mathrm{mL}^{-1}\right)$, and the lowest ones in the autumn $\left(26 \pm 7.4 \mathrm{ng} \cdot \mathrm{mL}^{-1}\right)$ and in the winter $\left(19.7 \pm 3.2 \mathrm{ng} \cdot \mathrm{mL}^{-1}\right)$.

\section{DISCUSSION}

The results of this study showed that adult female ibexes maintained under captive conditions displayed a period of ovulatory activity from December to January, followed by a long anoestrous period. The progesterone profiles revealed an oestrous cycle length similar to the cycle length of the domestic goat [22]. Our results revealed a high proportion of females with short cycles, which seems to be a characteristic of the caprine species and breeds [23-25], as well as females showing only one cycle of variable duration. It is unknown if these findings are usual in the wild. Ovulatory activity could be affected by captive conditions and isolation from males. In domestic goats, the sudden introduction of males affects the duration of the oestrous cycle [26]. In feral goats of Australia, the absence of males shortens the duration of ovulatory activity by about two months, by changing both the onset and the offset of the sexual activity [27]. The role of different social cues, such as the presence of a male, in the regulation of the ovulatory cyclicity and timing of seasonal anoestrous of the Spanish ibex is unknown and remains to be tested. However, this species exhibits a rich behavioural pattern in the wild, with complete sexual segregation outside the rut [13]. We thus assume that the buck's odour, physical contact and ritual behaviour are important factors in the control and duration of ovulatory activity.

It is not clear whether or not stress caused by captive conditions and blood recovery procedures could have affected our findings. In this regard, mouflons maintained at similar environmental conditions have a higher number of ovarian cycles (mean 10 cycles) of normal duration [14] than that detected in the ibex of the current study. Most investigators who have examined the role of stress in ovulatory activity have considered that stress appears to delay or abolish ovulation in some females [28, 29]. Specifically, stress reduces the normal pulsatile patterns of $\mathrm{GnRH}$ and, consequently, suppresses or delays the surge of LH $[30,31]$. The absence of ovulation in about half of the females might be explained, at least in part, by the wide between-individual range of variability in response to stressful conditions of captivity. However, cycles were not detected in females younger than 4 years old, suggesting that other factors might also account for the absence of cycles. The results suggest that ovulatory activity could be related to body weight. In our experimental conditions, the mean weight reached by the cycling ibex was about $28 \pm 0.9 \mathrm{~kg}$, which is close to the body weight previously established in adult females living in Sierra Nevada [17]. In contrast, field observations suggest that female Spanish ibexes do not mate until 2.5 years of age, when they reach a body weight higher than $24 \mathrm{~kg}[32,33]$. The lack of ovulation could therefore be associated 
with stress and liveweight, which may be related to the social status of the females in captive conditions. Previous studies in red deer (Cervus elaphus) suggest that corpus luteum function is affected by social status [34]. In rodents and monkeys, it has been demonstrated that only dominant females ovulate and inhibit the ovulation in subordinated females through aggression, visual cues and pheromones [35, 36]. In ibexes raised in captivity, the social interactions are reinforced and aggression directed towards dominated females (usually with lower bodyweight) has been frequently observed in our study. Specifically, the adult ibex with the highest aggressive behaviour towards other females showed a larger number of cycles (see ibex 570 in Fig. 1). Although reproductive suppression in the ibex raised in captivity could be under the control of the dominant breeder, we have not tested the individual level of dominance and subordination in all the females and furthermore studies are therefore needed to test this hypothesis.

Our results reveal a marked seasonality of reproduction, despite the fact that the ibexes originate and live in a temperate latitude. Ovulatory activity extends from December to January, which is in agreement with the timing of the rut period reported in field for ibexes living in the Sierra Nevada National Park [12]. In addition, the breeding season is similar to other ibex species originating from and living in higher latitudes, such as the Alpine ibex maintained both in wild [37] and captive conditions [38]. However, the ovulatory activity period was shorter than the mating season reported in wild or captive populations of the Spanish ibex living in other geographical areas of the Iberian Peninsula [15, 39]. This period was also shorter than that of other wild ruminant species living in the Iberian Peninsula at a similar or higher latitude [14]. Whether these differences are determined by a variable sensitivity to the photoperiod is not known. However, variations in photoperiodic response are seen not only between species but also between breeding populations within a species [40]. A higher sensitivity to the short photoperiod in the Spanish ibex from Sierra Nevada in relation with other populations may explain this variability in the length of the sexual active phase.

To our knowledge, no study has characterised the annual profile of prolactin secretion in the different species of the ibex. Photoperiod has been identified as the main environmental factor regulating the seasonal secretion of prolactin in many domestic and wild species adapted to cold and temperate climates [6, 41]. Furthermore heat stress may increase prolactin secretion [42]. The present study also revealed that plasma prolactin concentrations in the Spanish ibex were high during long days and low during short days. Basal levels were observed in October, similarly to domestic goats [43] and other wild species under the same environmental conditions, such as the mouflon [44]. However the timing of the increase in prolactin concentrations, in April, occurred three months later than in wild sheep and one month later than in domestic goats [43]. Genetic differences in response to photoperiodic changes may also explain this difference.

In conclusion, this study showed a very restricted breeding season, despite the fact that the Spanish Ibex originates and lives under a temperate latitude, revealing a remarkably good adaptation to the harsh climatic and nutritional conditions of their mountainous habitat. The data support the existence of a substantial influence of the age and body weight on the establishment of the ovulatory activity under captivity conditions, which should be taken into account in captive breeding programmes.

\section{ACKNOWLEDGEMENTS}

We express our gratitude to the National Wildlife Park of Sierra Nevada (Granada, Spain) for the generous provision of ibexes. This work was supported by CICYT grants AGL2000- 
1375, AGL2001-0335. JSM and AGB were supported by the Ramón y Cajal Research Programme from the Spanish Ministry of Science and Technology.

\section{REFERENCES}

[1] Cabrera A. The subspecies of Spanish ibex. Proc Zool Soc Lond 1911, 63-977.

[2] Granados JE, Chirosa M, Pérez MV, Pérez JM, Ruiz-Martínez I, Soriguer RC, Fandos P. Distribution and status of the Spanish ibex (Capra pyrenaica) in Andalusia, Southern Spain. In: Proc 2th World Conference Mountain Ungulates, Aosta, 1998, p 129-133.

[3] Munson L. Inbreeding and disease in captive wild animal. In: Fowler ME (Ed), Zoo and Wild Animal Medicine, WB Saunders Co., Philadelphia, Pennsylvania, 1993. p 73-79.

[4] Comizzoli P, Mermillod P, Mauget R. Reproductive biotechnologies for endangered mammalian species. Reprod Nutr Dev 2000, 40: 493-504.

[5] Loskutoff NM, Bartels P, Meintjes M, Godke RA, Schieve MC. Assisted reproductive technology in nondomestic ungulates: a model approach to preserving and managing genetic diversity. Theriogenology 1995, 43: 3-12.

[6] Lincoln GA. Correlation with changes in horns and pelage, but not reproduction, of seasonal cycles in the secretion of prolactin in rams of wild, feral and domesticated breeds of sheep. J Reprod Fertil 1990, 90: 285-296.

[7] Regisford EGC, Katz LS. Effects of bromocriptine-induced hypoprolactinaemia on gonadotrophin secretion and testicular function in rams (Ovis aries) during two seasons. J Reprod Fertil 1993, 99: 529-537.

[8] Regisford EGC, Katz LS. Effects of bromocriptine treatment on the expression of sexual behavior in male sheep (Ovis aries). $\mathrm{J}$ Anim Sci 1994, 72: 591-597.

[9] Dunbar EP, Dunbar R. Competition and niche separation in a high-altitude herbivore community in Ethiopia. Afr J Ecol 1981, 19: 251-263.

[10] Nievergelt B. Walia Ibex. In: Grzimek B (Ed), Grzimek's Encyclopedia of Mammals, McgrawHill Publishing Company, New York, 1990. p 523-525.

[11] Nievergelt B. A comparison of rutting behaviour and grouping in the Ethiopian and Alpine ibex. In: Geist V, Walther F (Eds), The Behaviour of Ungulates and its relation to Management, IUCN Publication, Morges, 1974. p 324-340.

[12] Rodríguez M. La cabra montés de Sierra Nevada. Serie Cinegética (1). Ministerio de
Agricultura, Servicio de Pesca Continental, Caza y Parques Nacionales (Ed), Madrid, 1969.

[13] Alados CL, Escós J. Ecología y Comportamiento de la Cabra Montés. Consideraciones para su gestión. Monografías. Museo Nacional de Ciencias Naturales, CSIC, Madrid, 1996.

[14] Santiago-Moreno J, González-Bulnes A, Gómez-Brunet A, López-Sebastián A, Tortonese DJ. The timing of the onset of puberty, extension of the breeding season and length of post-partum anoestrus in the female European Mouflon (Ovis gmelini musimon). J Zoo Wildl Med 2001, 32: 230-235.

[15] Losa-Huecas J. El Macho Montés. Exposición monográfica de una pieza de caza, Junta de Castilla y León. Consejería de medio Ambiente y Ordenación del Territorio Publ. Valladolid, 1993.

[16] Alados CL, Escos J. La cabra montés de las Sierras de Cazorla y Segura. Una introducción al estudio de sus poblaciones y comportaminet. Naturalia Hispanica (28), Ministerio de Agricultura, Pesca y Alimentación, ICONA Publ., Madrid, 1985.

[17] Granados JE, Fandos P, Márquez FJ, Soriguer RC, Chirosa M, Pérez JM. Allometric growth in the Spanish ibex, Capra pyrenaica. Folia Zool 2001, 50: 234-238.

[18] López-Sebastián A, Gómez-Brunet A, Inskeep EK. Effects of a single injection of LH-RH on the response of anestrous ewes to the introduction of rams. J Anim Sci 1984, 59: 277-283.

[19] Gómez-Brunet A, Lopez-Sebastian A. Effect of season on plasma concentrations of prolactin and cortisol in pregnant, non-pregnant and lactating ewes. Anim Reprod Sci 1991, 26: 251-268.

[20] English J, Poulton AL, Arendt J, Symons AM. A comparison of the efficiency of melatonin treatments in advancing oestrus in ewes. Reprod Fertil 1986, 77: 321-327.

[21] Maeda KI, Lincoln GA. Phase shifts in the circadian rhythm in plasma concentrations of melatonin in rams induced by a 1-hour light phase. J Biol Rhythm 1990, 5: 97-106.

[22] Chemineau P. Sexual behaviour and gonadal activity during the year in the tropical Creole meat goat. I. Female oestrous behaviour and ovarian activity. Reprod Nutr Dev 1986, 26: 441-452.

[23] Chemineau P. Effect of oestrus and ovulation of exposing creole goats of the male at three times of the year. J Reprod Fertil 1983, 67: 65-72.

[24] Corteel JM. L'insémination artificielle caprine: bases physilogiques, état actuel et perspectives d'avenir. World Re Anim Prod 1973, 9: 73-99.

[25] González-Stagnaro C. Comportamiento reproductivo de las razas locales de rumiantes en el trópico americano. In: Chemineau P, Gauthier 
D, Thimonier J, Reproduction des rumiants en zone tropicale. Coll. INRA 20, 1983, p 1-84.

[26] Chemineau P. Possibilities for using bucks to stimulate ovarian and oestrous cycles in anovulatory goats - a review. Livest Prod Sci 1987, 17: 135-147.

[27] Restall BJ. Seasonal variation in reproductive activity in Australian goats. Anim Reprod Sci 1992, 27: 305-318.

[28] Cameron AW, Battye KM, Trounson AO. Time of ovulation in goats (Capra hircus) induced to superovulate with PMSG. J Reprod Fertil 1988, 83: 747-752.

[29] Macfarlane MS, Breen KM, Sakurai H, Adams BM, Adams TE. Effect of duration of infusion of stress-like concentrations of cortisol on follicular development and the preovulatory surge of LH in sheep. Anim Reprod Sci 2000, 63: $167-175$.

[30] Dobson H, Tebble JE, Smith RF, Ward WR. Is stress really all that important? Theriogenology 2001, 55: 65-73.

[31] Martin GB, Oldham CM, Lindsay DR. Effect of stress due to laparoscopy on plasma cortisol levels, the preovulatory surge of $\mathrm{LH}$ and ovulation in the ewe. Theriogenology 1980, 16: 39-44.

[32] Fandos P. Reproductive strategies in female Spanish ibex (Capra pyrenaica). J Zool Lond. 1989, 218: 339-343.

[33] Fandos P. La cabra montés (Capra pyrenaica) en el Parque Natural de Cazorla, Segura y Las Villas. Colección Técnica, Icona, Madrid, 1991.

[34] Flint AP, Albon SD, Jabbour HN. Behavioral dominance and corpus luteum function in red deer (Cervus elaphus). Horm Behav 1997, 31: 296-304.

[35] Barrett J, Abbott DH, George, LM. Sensory cues and the suppression of reproduction in subordinate female marmoset monkeys, Callithrix jacchu. J Reprod Fertil 1993, 97: 301-310.

[36] Clarke FM, Miethe GH, Bennett NC. Reproductive suppression in female Damaraland mole- rats Cryptomys damarensis: dominant control or self-restraint? Proc R Soc Lond Biol Sci 2001, 268: 899-909.

[37] Giacometi M. On the reproductive performance and population dynamics of the Alpine ibex (Capra ibex ibex) in the colony of Albris (Grisons, Switzerland). In: Congreso Internacional del Género Capra en Europa, Ronda, 1992, p 149-153.

[38] Stüwe M, Grodinsky C. Reproductive biology of captive alpine ibex (Capra ibex ibex). Zoo Biol 1987, 6: 331-339.

[39] Fernández-Arias A, Alabart JL, Echegoyen E, Sánchez P, Folch J. Parámetros reproductivos de la cabra montés (Capra pyrenaica hispanica) en cautividad. ITEA Vol Extra 2001, 22: 745-747.

[40] Goldman BD. Mammalian photoperiodic system: formal properties and neuroendocrine mechanisms of photoperiodic time measurement. J Biol Rhythms 2001, 16: 283-301.

[41] Lincoln GA. Significance of seasonal cycles in prolactin secretion in male mammals. In: Perspectives in Andrology (Serono Symposia Publications). M. Serio. Raven Press (Ed.), New York 1989, 53: 299-306.

[42] Schillo KK, Alliston CW, Malven PV. Plasma concentrations of luteinizing hormone and prolactin in the ovariectomized ewe during induced hyperthermia. Biol Reprod 1978, 19: 306-313.

[43] Prandi A, Motta M, Chiesa F, Tamanini C. Circannual rhythm of plasma prolactin concentration in the goat. Anim Reprod Sci 1988, 17: 85-94.

[44] Santiago-Moreno J, López-Sebastián A, González-Bulnes A, Gómez-Brunet A, Chemineau P. Seasonal changes in ovulatory activity, plasma prolactin and melatonin concentration in Mouflon (Ovis gmelini musimon) and Manchega (Ovis aries) ewes. Reprod Nutr Dev 2000, 40: 421-430. 